\title{
REGULATORY MECHANISMS OF UKRAINIAN PHARMACEUTICAL MARKET COMPETITIVENESS IN THE CONTEXT OF EUROPEAN INTEGRATION
}

\author{
Iryna Budnikevych ${ }^{1}$, Vadym Honchar ${ }^{2}$
}

\begin{abstract}
The purpose of the paper is to summarize and present the differences in the competitive environment of the European Union (EU) and Ukrainian pharmaceutical markets. The method of longitudinal study allowed to detect the patterns of changes and correlations for pharmaceutical products exports and imports volumes over twenty years (2001-2020). Methodology. The research is based on the definition of the pharmaceutical market as a complex socio-economic institution that fulfills the function of pricing medical products and utilizes them to ensure health care functioning. It indicates the population's wellbeing and requires ongoing maintenance based on needs agreement of households, economic entities, and the state. The quantitative research is based on export-to-import coverage ratio calculations with the identification of pharmaceutical products fraction in the total volume of foreign trade, including the one with the EU. The results of the paper consist in the evaluation of the competitive environment of the European Union's pharmaceutical market and statistical assessment of Ukrainian foreign trade of pharmaceutical products. They also include the definition of the European integration influence over the Ukrainian pharmaceutical market and well-reasoned recommendations about the application of the state and trade regulation mechanisms. In the paper, we defined the distinctive features of the European countries' pharmaceutical markets and outlined their main characteristics that have connections to the transnational corporation's activities, common market, and high concentration. Statistical data collected over 20 years indicated the dynamic development of the Ukrainian pharmaceutical market, despite its small-scale contribution to the foreign trade turnover. The dependence of Ukraine on the foreign supplies of drugs and medications is illustrated by the multiple excesses of imports over exports, especially in the trade relationships with the EU. The EU countries are the leading importers of pharmaceutical products to the Ukrainian market. However, the share of medical supplies exports from Ukraine to the EU countries is negligible. Their key exporters are post-Soviet and developing countries. The growth in Ukraine's export potential is inextricably linked to the expansion of the competitiveness of domestic medical supplies. Practical implications consist in the development of recommendations concerning the GMP and GDP demands realization, domestic manufacturers cooperation with the leading foreign pharmaceutical companies, the penetration of transnational companies into the Ukrainian domestic pharmaceutical market based on imports of innovative technologies, the improvement of the marketing management of the pharmaceutical products exporting. The priority factor in the growth of the competitiveness of the Ukrainian pharmaceutical market is a successful combination of state and trade regulation mechanisms. The objects of these factors are the pricing policy for material resources and finished products, the introduction of innovations, tax exemptions, and export-import quotas implementation. They also include the establishment of traffic rates that depend on the market saturation with socially significant medical supplies, budget support of the prioritized subsectors of the pharmaceutical industry, and patent protection. The expected results concern the decrease in the dependence of the Ukrainian pharmaceutical market on the foreign distribution of the raw materials and finished products and strengthening the positions of the Ukrainian manufacturers in foreign markets. Value/originality. We evaluated the competitiveness of the national pharmaceutical market based on
\end{abstract}

\footnotetext{
Corresponding author:

${ }^{1}$ Yuriy Fedkovych Chernivtsi National University, Ukraine.

E-mail: i.budnikevich@chnu.edu.ua

ORCID: https://orcid.org/0000-0002-5466-6532

ResearcherID: http://www.researcherid.com/D-2876-2017

${ }^{2}$ Yuriy Fedkovych Chernivtsi National University, Ukraine.

E-mail: vadhonchar@gmail.com

ORCID: https://orcid.org/0000-0002-8252-0573
} 
the criteria of foreign trade performance and detected the priorities of its growth, taking into consideration the synthesis of the state and trade regulation mechanisms.

Key words: competitiveness, pharmaceutical market, national economy, European integration, market, state regulation.

JEL Classification: D41, F02, F12, F15, L51, L65, O33

\section{Introduction}

In the national economies of world's countries, the pharmaceutical market is a complex structural element that plays a vital role in the fulfillment of a dominant social function related to public health care. As an economic indicator, it represents the level of the populations' wellbeing. Specifically, the increase in the capacity of the pharmaceutical market shows the growing capabilities of residents to satisfy the need to maintain high standards of living. An agreement of the needs of households, economic entities, and states emphasizes the operation of market and state mechanisms that regulate the pharmaceutical segment of the national economy. The main feature of the highly developed markets is the use of innovations since their competitiveness is linked to the establishment and promotion of new pharmaceutical products. The members of the pharmaceutical market fall into four main categories. They include innovative branded companies that conduct research and development of new products, generic companies that enable the output of the products that are no longer under patent protection, biotechnological (biotech) companies that can produce both patented and generic medical supplies, companies utilizing the raw materials of either homeopathic or chemical nature (Bekarev, Bekareva, 2014).

The features of the modern pharmaceutical market development are the acceleration of its output consumption in the developing countries, the expiry of the patent protection for the significant number of branded medical supplies, the reduction of incomes and market share of the branded pharmaceutical businesses. Certain segments of the pharmaceutical market have their distinctive competitive advantages. Patented companies produce products of higher quality, while generic ones set lower prices and are more accessible for the average consumer. The introductory prices depend on the degree of therapeutic innovation and price regulation discourages price competition between brand-name drugs (Ekelund, Persson, 2003). The results indicate that physicians often fail to internalize patient costs, explaining why cheaper generics are infrequently adopted. However, generics' markup advantages are short-lived, which limits their impact on increasing generic adoption (Iizuka, 2012).

Legal regulation has a significant influence on the competitive environment of the pharmaceutical market. Such detrimental factors as the lack of legislative protection of branded companies, weaknesses in the patent law, and ineffective prevention of falsified medical supplies turnover worsen conditions of the competitive environment. Patent enforcement in developing countries generates considerable controversy, especially when patents involve potentially life-saving drugs. Because prices in developing countries are much lower than in the developed world, multinationals may choose to enter such markets with a delay, or not at all, implying a complete loss of access to patented drugs in developing countries. Such considerations may provide a justification for policies targeting access in the short and medium run, such as compulsory licensing (Goldberg, 2010). The turnover of the pharmaceutical products must comply with the regulations of Trade-Related Aspects of Intellectual Property Rights (TRIPS) of the World Trade Organization (Duggan, Garthwaite, Goyal, 2016).

The integration of Ukraine into the world economic area requires the protection of its national market competition, in particular of the pharmaceutical one. Its role is objectively growing as humanity faces new challenges. One of the issues is especially urgent in the health care field, as there is a pressing need to combat coronavirus infection.

\section{Competitive environment of the EU pharmaceutical market}

The world pharmaceutical market is divided into clusters represented by the following groups of consolidated countries: North America, Western Europe, Central and Eastern Europe, Japan, Middle East, Asia and Latin America, other Asian and African countries. Socially-oriented economies of Western and Northern European countries determine their substantial and highly developed 
pharmaceutical markets. They feature in the population's high standards of living that result in residents aging, notable budget spending on health care, and excellent competitive environment. Central and Eastern European pharmaceutical markets are defined by lower economic efficiency due to deteriorated living conditions, modest healthcare expenditures, the dominance of generic medications, and the significant dependence of the national markets on the imported pharmaceutical supplies. The last-mentioned issue occurred due to the transformational processes that came into action in post-Soviet countries in the 1990s. There was a crisis in the state-run pharmaceutical industry and the introduction of the private economic segment.

In the European Union (EU), traditional price differentials for pharmaceutical products between countries are being undermined by parallel trade and regulation based on foreign prices. This break down of market segmentation leads manufacturers to adopt uniform prices EU-wide. Efficiency and distributive effects of such policies are probably negative. Monopsony is a more serious problem in the EU, hence actual price differentials may exceed Ramsey optimal differences. Confidential contracts between manufacturers and governments, including rebates off a common list price, would preserve ex post price differentials and should be consistent with the EU law (Danzon, 1997). The main market players in the EU pharmaceutical industry are the largest transnational companies that were created by means of mergers and takeovers, and they continue such integration (Tronenko, 2014). The central and Eastern European pharmaceutical market consists in the significant concentration and consolidation. For example, 10 participants of the market hold almost $90 \%$ of sales. Legal mechanisms of economic principles maintenance in the pharmaceutical market of the EU target the combination of goals of the EU single domestic market of medical supplies and social aims oriented on the protection of consumers and patients' interests. In the wide perspective they include the protection of individuals' rights and interests (Pasechnyk, 2014).

\section{Ukrainian foreign trade of pharmaceutical products}

Imports and exports are the indicators of Ukraine's international trade of pharmaceutical products. They have the recurrent dynamics from
2001 to 2020 and are tightly related. It is illustrated by the high value of the correlation coefficient, which is equal to 0.8739 (Table 1 ).

The average share of pharmaceutical products exports equals only $0.35 \%$ of the total exports. The average mean of medical supplies imports is $3.41 \%$ of total imports. Therefore, the foreign trade of pharmaceutical products does not play a significant role in the balance of payments formation.

In the structure of foreign trade, the share of pharmaceutical products imports significantly surpasses the share of exports (11.53 times on average). From 2001 to 2008, the value of the export-to-import coverage ratio grew from 6.88 to 16.22 . Over the next years, there was a downward trend of the stated index, which decreased to 8.65 in 9 months of 2020. The dynamics of the coefficient is illustrated by the parabola that opens downward with the significant level of multiple determination coefficient $\left(\mathrm{R}^{2}=0.7101\right)$. The formalization by the equation is as follows:

$$
y=-0,079 x 2+1,4514 x+7,2854
$$

From 2001 to 2012, the scope of pharmaceutical products exports surged 9.64 times from 342593.66 thousand USD to 3303002.4 thousand USD (historical peak point). The dynamics of pharmaceutical products' imports is similar. There was a 5.13 times increase from 49831.68 thousand USD to 255591.6 thousand USD. Therefore, we observe a surpassing growth in the value of export transactions as compared to imports. The most rapid growth rates of a pharmaceutical products foreign trade volume occurred between 2003 and 2007. By 2015, foreign trade performance saw downward dynamics as the exports went down to 1367034.5 thousand USD (by $58.5 \%$ relatively to the historical maximum). Imports decreased to 155441.6 thousand USD (by $39.2 \%$ ). Relative estimates show that exports decreased by $39.2 \%$ in 2015, and imports by $44.5 \%$ compared to the previous period. By the end of the analyzed period (2019), foreign trade turnover indicates an upward trend. Thus, exports rose to 2143147.0 thousand USD, and imports increased up to 250792.2 thousand USD, which corresponded to the tendencies of 2014.

The imbalance between imports and exports of pharmaceutical products in international trade with the EU is even more dramatic (Table 2). The average mean of the export-to-import coefficient during 2018 and 9 months of 2020 is 73.35 times. 
Table 1

The dynamics of indicators of the Ukrainian foreign trade of the pharmaceutical products

\begin{tabular}{|c|c|c|c|c|c|c|c|}
\hline \multirow[b]{2}{*}{ Years } & \multicolumn{3}{|c|}{ Exports } & \multicolumn{3}{|c|}{ Imports } & \multirow[b]{2}{*}{$\begin{array}{c}\text { export- } \\
\text { to-import } \\
\text { coverage ratio }\end{array}$} \\
\hline & thsd. USD & $\begin{array}{l}\text { in } \% \text {, to the } \\
\text { corresponding } \\
\text { period of the } \\
\text { previous year }\end{array}$ & $\begin{array}{c}\% \text { of the total } \\
\text { volume }\end{array}$ & thsd. USD & $\begin{array}{l}\text { in } \% \text {, to the } \\
\text { corresponding } \\
\text { period of the } \\
\text { previous year }\end{array}$ & $\begin{array}{c}\% \text { of the total } \\
\text { volume }\end{array}$ & \\
\hline 2001 & 49831.68 & 118.48 & 0.31 & 342593.66 & 131.18 & 2.17 & 6.88 \\
\hline 2002 & 42920.18 & 86.13 & 0.24 & 427893.01 & 124.90 & 2.52 & 9.97 \\
\hline 2003 & 54135.53 & 126.13 & 0.23 & 596826.62 & 139.48 & 2.59 & 11.02 \\
\hline 2004 & 66272.51 & 122.40 & 0.20 & 745494.59 & 124.97 & 2.5 & 11.25 \\
\hline 2005 & 82221.21 & 124.07 & 0.24 & 1043904.7 & 140.03 & 2.89 & 12.70 \\
\hline 2006 & 92487.6 & 112.7 & 0.2 & 1384877.2 & 132.7 & 3.1 & 14.97 \\
\hline 2007 & 129446.6 & 140.0 & 0.3 & 1931315.9 & 139.5 & 3.2 & 14.92 \\
\hline 2008 & 151071.8 & 116.7 & 0.2 & 2433303.7 & 126.0 & 2.8 & 16.11 \\
\hline 2009 & 150046.4 & 99.3 & 0.4 & 2130331.5 & 87.5 & 4.7 & 14.20 \\
\hline 2010 & 198731.4 & 132.5 & 0.4 & 2459867.5 & 115.6 & 4.1 & 12.38 \\
\hline 2011 & 194866.4 & 98.1 & 0.3 & 2873504.7 & 116.8 & 3.5 & 14.75 \\
\hline 2012 & 243106.9 & 124.8 & 0.4 & 3303002.4 & 114.9 & 4.0 & 13.59 \\
\hline 2013 & 250849.6 & 103.2 & 0.4 & 3094782.7 & 93.7 & 4.1 & 12.34 \\
\hline 2014 & 255591.6 & 101.9 & 0.5 & 2473307.8 & 79.9 & 4.5 & 9.68 \\
\hline 2015 & 155441.6 & 60.8 & 0.4 & 1367034.5 & 55.3 & 3.6 & 8.79 \\
\hline 2016 & 184182.8 & 118.5 & 0.5 & 1606956.3 & 117.6 & 4.1 & 8.72 \\
\hline 2017 & 192111.3 & 104.3 & 0.4 & 1767455.8 & 110.0 & 3.6 & 9.20 \\
\hline 2018 & 216178.0 & 112.5 & 0.5 & 1947012.5 & 110.2 & 3.4 & 9.01 \\
\hline 2019 & 250792.2 & 116.0 & 0.5 & 2143147.0 & 110.1 & 3.5 & 8.55 \\
\hline 9 months 2020 & 191796.6 & 107.9 & 0.5 & 1659235.8 & 110.8 & 4.4 & 8.65 \\
\hline Average index & $\mathrm{x}$ & $\mathrm{x}$ & 0.35 & $\mathrm{x}$ & $\mathrm{x}$ & 3.41 & 11.53 \\
\hline
\end{tabular}

Source: State Statistics Service of Ukraine (2020)

Table 2

The dynamics of indicators of the Ukrainian foreign trade of the pharmaceutical products with the EU

\begin{tabular}{|c|c|c|c|c|c|c|c|}
\hline \multirow[b]{2}{*}{ Years } & \multicolumn{3}{|c|}{ Exports } & \multicolumn{3}{|c|}{ Imports } & \multirow[b]{2}{*}{$\begin{array}{c}\text { export- } \\
\text { to-import } \\
\text { coverage ratio }\end{array}$} \\
\hline & thsd. USD & $\begin{array}{l}\text { in } \% \text {, to the } \\
\text { corresponding } \\
\text { period of the } \\
\text { previous year }\end{array}$ & $\begin{array}{c}\% \text { of the total } \\
\text { volume }\end{array}$ & thsd. USD & $\begin{array}{l}\text { in } \% \text {, to the } \\
\text { corresponding } \\
\text { period of the } \\
\text { previous year }\end{array}$ & $\begin{array}{c}\% \text { of the total } \\
\text { volume }\end{array}$ & \\
\hline 2018 & 21736.2 & 149.0 & 0.1 & 1418666.0 & 109.8 & 6.1 & 65.27 \\
\hline 2019 & 23420.4 & 107.7 & 0.1 & 1562688.2 & 110.2 & 6.2 & 66.72 \\
\hline 9 months 2020 & 13801.5 & 81.5 & 0.1 & 1215409.0 & 110.5 & 7.4 & 88.06 \\
\hline \multirow[t]{2}{*}{ Average index } & $\mathrm{x}$ & $\mathrm{x}$ & 0.1 & $\mathrm{x}$ & $\mathrm{x}$ & 6.57 & 73.35 \\
\hline & \multicolumn{7}{|c|}{ The proportion in the total foreign trade, $\%$} \\
\hline 2018 & 10.05 & $\mathrm{x}$ & $\mathrm{x}$ & 72.86 & $\mathrm{x}$ & $\mathrm{x}$ & $\mathrm{x}$ \\
\hline 2019 & 9.34 & $\mathrm{x}$ & $\mathrm{x}$ & 72.92 & $\mathrm{x}$ & $\mathrm{x}$ & $\mathrm{x}$ \\
\hline 9 months 2020 & 7.20 & $\mathrm{x}$ & $\mathrm{x}$ & 73.25 & $\mathrm{x}$ & $\mathrm{x}$ & $\mathrm{x}$ \\
\hline Average index & 8.86 & $\mathrm{x}$ & $\mathrm{x}$ & 73.01 & $\mathrm{x}$ & $\mathrm{x}$ & $\mathrm{x}$ \\
\hline
\end{tabular}

Source: State Statistics Service of Ukraine (2020)

The average share of pharmaceutical products exports in total exports to the EU countries amounts to only $0.1 \%$. Pharmaceutical products imports constitute $6.57 \%$ of total imports. Therefore, the import indicators are noticeable in the foreign trade structure because pharmaceutical products exports do not play a significant role in forming the balance of payments.

The EU is the leading supplier of the imported medical products to Ukraine. The share of the 
product delivered is $73 \%$ on average out of total imports of pharmaceutical products. On the contrary, Ukraine exports to the EU only $8.86 \%$ of the total volume of the exported pharmaceutical products. Following the results of 2019, the dominant share of medical supplies produced in Ukraine is exported to the following countries: Uzbekistan (21.36\%), Brazil (11.97\%), Belarus (9.58\%), Kazakhstan (8.59\%), The Republic of Moldova (6.06\%), the Russian Federation (5.91\%), Azerbaijan (4.97\%), Georgia (4.84\%), Iraq (3.89\%), Lithuania (3.46\%), India (3.02\%), Kyrgyzstan (2.47\%), Turkmenistan (1.76\%), Latvia (1.55\%), Vietnam (1.17\%), Germany $(1.01 \%)$. The proportion of delivery to other countries is less than $1 \%$. The harmonization of the main technical requirements for pharmaceutical products based on the European Union obligations is a pre-requisite for the realization of the export motivation of the domestic manufacturers and the protection from the competitiveness with lowquality imports.

\section{The influence of European Integration over the pharmaceutical market of Ukraine}

The implementation of European regulations concerning public health care, medical supplies turnover, and quality control is a vital direction of Ukrainian pharmaceutical integration into the global market (Kovalenko, 2014). Some of the positive actions our country takes in this direction are the formation of the State Drugs and Medications Control Service in September 2014 and its membership in the Pharmaceutical Inspection Convention (PIC) and Pharmaceutical Inspection Co-operation Scheme (PIC/S). Ukraine fulfilled the GMP and Good Distribution Practice (GDP) requirements for medical supplies and joined the World Health Organization system of medical products quality certification.

Cooperation between domestic and foreign medical product manufacturers strengthens the external and internal competitiveness of the Ukrainian pharmaceutical market. It occurs in the form of joint ventures, alliances, group marketing strategies, the promotion of products, and the transfer of the over-the-counter (OTC) drugs production to Ukraine (Kostiuk, Kovalenko, 2013). Spreading the transnational corporation's influence over the operating and investment spheres of domestic pharmaceutical business activities facilitates the improvement of technical and technological production levels. It ensures innovation and high quality of industry's production, extends the export potential, and reorients it to the developed markets, including the European ones.

The factors that foster competitiveness in the pharmaceutical market are a significant scope of wholesale and retail commodity turnover, as well as considerable personnelrelated, educational, research, and production potentials in the pharmaceutical sector. Some aspects restrict competitiveness. They include an insignificant share of pharmaceutical businesses in Ukraine that are also certified for compliance with European standards of Good Manufacturing Practice (GMP) and a low proportion of Ukraine's original and biotechnological medical supplies. Raw materials needed to produce drugs and medicals are limited and depend on the imports of pharmaceutical substances. Domestic goods do not meet the demands of the European quality standards and certification requirements. The worn-out physical infrastructure fails to keep up with the time, and there are no investments to upgrade it. The innovation activity of domestic producers is low, and there is a lack of government contracts for purchasing products of the Ukrainian pharmaceutical industry. Other restrictions are the faulty mechanisms of providing budget support, pricing, and managing the pharmaceutical market (Dorovskyi, 2015; Derbenova, 2017).

\section{The mechanisms of state and market regulation}

The mechanisms of state regulation are oriented toward improving the competitiveness of the Ukrainian pharmaceutical market. They include the regulation of prices and tariffs for material resources dedicated to the production of medical supplies, mostly - sources of energy. They feature tax benefits, customs controls of the innovative activities, and the implementation of special quotas for exports and imports of cutting-edge equipment, technologies, and pharmaceutical products. Regulative institutions must assist the local pharma manufacturers in foreign markets entering, encourage the exports by the state's monetary policy, obtain exporting preferences, and promote the development of international and industrial custom logistics. They perform deregulation to decrease the transactional expenditure on licensing procedures for business 
activities in the pharmaceutical market and the admission of medical products to it (Korolenko, Holovatiuk, 2017).

External and internal markets are the areas of competitiveness for domestic pharmaceutical producers. Compared to foreign companies, they have a competitive weakness in terms of products' quality since they release generics mostly (non-original products). Their competitive advantage, however, is associated with low prices. Nevertheless, the distinctive feature of the Ukrainian pharmaceutical market is the expansion of the branded production of medical supplies that enlarges the final consumer costs. Mechanisms regulating the pharmaceutical market must consider the characterization of medications as goods or non-consumer products (due to the maturity stage of the life cycle, episodic nature of purchases). They are associated with the establishment of a selective type of distribution, maximum supplierbuyer proximity, the placement in the housing estates and health care facilities, E-Commerce, and postal delivery (Ustymenko, 2011). Strengthening the competitiveness of Ukraine on external pharmaceutical market also allows for the formation of distribution and establishment channels, as well as the development of long-term relationships with the European mediators (dealers, distributors). Other market mechanisms consist of the intensification of international cooperation of domestic and foreign medicine manufacturers in the technical and technological domains. They include foreign investments that enable the conduction of research works and the creation of innovative products in the pharmaceutical industry. Market mechanisms optimize external and internal logistics chain of supply, production, and distribution of pharmaceutical products, improve the risk management system, and implement European standards of health care and pharmaceutics reformation (Lytvynenko, Sobkova, 2015).

Local manufactures of pharmaceutical products and medical equipment are forced to copy medications, cutting-edge equipment and imitate the process of creative development of advanced technologies. There is a suggestion to apply the following principles to improve the patent protection of the pharmaceutical market. The dominant condition of acknowledging drugs and medications as the new product is if there is a significant difference in the qualities that affect the efficiency of therapy. If it is lacking a new therapeutic effect to its famous alternatives, there is a reason to consider such medical treatments as non-patentable. It is necessary to provide legal protection strictly to the products that fall into the category of medical products (Olefir, 2016).

\section{Conclusions}

The pharmaceutical market is a complex socioeconomic institution that fulfills the function of pricing medical products and applies them to ensure health care functioning. It indicates the population's wellbeing and requires ongoing maintenance aligned to the needs of households, economic entities, and the state, using the coordinated market and state regulation mechanisms.

In the paper, we performed the division of pharmaceutical companies into categories depending on their level of innovation and the nature of products released. We determined the competitive advantages and disadvantages of certain groups of medical products (patented and generics) and defined the consuming tendencies in countries depending on their development. The research paper illustrates the significant influence of patent law and commercial aspect of intellectual property rights over the development of a competitive environment in the pharmaceutical market.

We determined the distinctive features of the pharmaceutical markets of Western and Northern European countries in comparison to the countries of Central and Eastern Europe, as well as outlined the main characteristics that have connections to the transnational corporations' activity, common market, and high concentration.

Statistical data collected over 20 years indicated the dynamic development of the Ukrainian pharmaceutical market, despite its small-scale contribution to the foreign trade turnover. The dependence of Ukraine on the foreign supplies of drugs and medications is illustrated by the multiple excesses of imports over exports, especially in the trade relationships with the EU. The EU countries are the leading importers of pharmaceutical products to the Ukrainian market. To the contrary, the share of medical supplies exports from Ukraine to the EU countries is negligible. Their leading exporters are post-Soviet and developing countries. The growth of Ukraine's export potential is inextricably linked to the expansion of the competitiveness of domestic medical supplies.

The main results of the European Integration processes influence over the Ukrainian 
pharmaceutical market are the implementation of the European regulations concerning public health care, medical supplies turnover, and quality control. They include the creation of the corresponding supervisory institutions, the membership in PIC/S, the fulfillment of GMP and GDP requirements, and joining the World Health Organization system of medical products quality certification. The competitiveness of the domestic manufacturers of pharmaceutical products will be improved by the cooperation with the leading foreign pharmaceutical firms, the penetration of transnational companies into the Ukrainian domestic pharmaceutical market based on imports of innovative technologies, the improvement of the marketing management of the pharmaceutical products exporting.

The priority factor in the growth of the Ukrainian pharmaceutical market competitiveness is a successful combination of state and trade regulation mechanisms. The objects of these factors are the pricing policy for material resources and finished products, the introduction of innovations, tax exemptions, and export-import quotas implementation. They include the establishment of traffic rates that depend on the market saturation with socially significant medical supplies, budget support of the prioritized subsectors of the pharmaceutical industry, and patent protection.

Decent synthesis of the mentioned mechanisms will facilitate the elimination of disproportions between exports and imports of medical supplies. The expected results concern the decrease in the dependence of the Ukrainian pharmaceutical market on the foreign distribution of the raw materials and finished products and strengthening the positions of the Ukrainian manufacturers in foreign markets.

\section{References:}

Bekarev, A. A., \& Bekareva, S. V. (2014). Podkhod k otcenke konkurentosposobnosti natcionalnoi farmatcevticheskoi otrasli [An approach to assessing the competitiveness of the national pharmaceutical industry]. Novosibirsk State University Bulletin. Series: Socio-economic sciences, vol. 14(4), pp. 78-91.

Danzon, P. M. (1997). Price Discrimination for Pharmaceuticals: Welfare Effects in the US and the EU. International Journal of the Economics of Business, vol. 4(3), pp. 301-322. doi: 10.1080/758523212

Derbenova, Ya. V. (2017). Potentsial pidvyshchennia konkurentospromozhnosti farmatsevtychnoi haluzi Ukrainy na natsionalnomu ta mizhnarodnomy rynkakh [Potential to increase the competitiveness of the pharmaceutical industry of Ukraine in the national and international markets]. Problems of innovation and investment development, vol. 10, pp. 3-7.

Dorovskyi, O. V. (2015). Metodychnyi pidkhid do otsinky konkurentospromozhnosti farmatsevtychnoi haluzi Ukrainy [Methodical approach to assessing the competitiveness of the pharmaceutical industry of Ukraine]. Financial space, vol. 2, pp. 358-368.

Duggan, M., Garthwaite, C. \& Goyal, A. (2016). The Market Impacts of Pharmaceutical Product Patents in Developing Countries: Evidence from India. American Economic Review, vol. 106(1), pp. 99-135. doi: $10.1257 /$ aer.20141301

Ekelund, M., \& Persson, B. (2003). Pharmaceutical Pricing in a Regulated Market. Review of Economics and Statistics, vol. 85(2), pp. 298-306. doi: 10.1162/003465303765299828

Goldberg, P. K. (2010). Intellectual Property Rights Protection in Developing Countries: The Case of Pharmaceuticals. Journal of the European Economic Association, vol. 8(2-3), pp. 326-353. doi: $10.1111 /$ j.1542-4774.2010.tb00506.x

Iizuka, T. (2012). Physician Agency and Adoption of Generic Pharmaceuticals. American Economic Review, vol. 102(6), pp. 2826-58. doi: 10.1257/aer.102.6.2826

Korolenko, N. V., \& Holovatiuk, O. S. (2017). Lohistychne upravlinnia yak faktor pidvyshchennia mizhnarodnoi konkurentospromozhnosti ukrainskykh farmatsevtychnykh pidpryiemstv [Logistics management as a factor in increasing the international competitiveness of Ukrainian pharmaceutical companies]. Efficient economy, 1. Available at: http://nbuv.gov.ua/UJRN/efek_2017_1_20 (accessed 10 November 2020).

Kostiuk, H. V., \& Kovalenko, A. V. (2013). Konkurentospromozhnist farmatsevtychnoi promyslovosti Ukrainy [Competitiveness of the pharmaceutical industry of Ukraine]. Efficient economy, vol. 11. Available at: http://nbuv.gov.ua/UJRN/efek_2013_11_94 (accessed 10 November 2020).

Kovalenko, I. (2014). Kryminalna vidpovidalnist za falsyfikatsiiu likarskykh zasobiv - vazhlyvyi krok adaptatsii farmatsevtychnoi haluzi do notm Yevropeiskoho Soiuzu [Criminal liability for falsification of medicines is an important step in the adaptation of the pharmaceutical industry to the norms of the European Union]. Legal Bulletin, vol. 1, pp. 262-266. 
Lytvynenko, L. L., \& Sobkova, A. O. (2015). Perspektyvy rozvytku farmatsevtychnoho rynku Ukrainy v umovakh pohlyblennia protsesiv yevrointehratsii [Prospects for the development of the pharmaceutical market of Ukraine in the conditions of deepening of European integration processes]. Problems of improving the efficiency of infrastructure, vol. 40, pp. 51-57.

Olefir, A. O. (2016). Obmezhennia sfery patentnoi okhorony yak zasib vidnovlennia konkurentospromozhnosti farmatsevtychnoi promyslovosti [Limiting the scope of patent protection as a means of restoring the competitiveness of the pharmaceutical industry]. Theory and practice of intellectual property, vol. 2, pp. 28-40.

Pasechnyk, O. V. (2014). Pravove zabezpechennia farmatsevtychnoi polityky Yevropeiskoho Soiuzu [Legal support of the pharmaceutical policy of the European Union]. Scientific Bulletin of the International Humanities University. Series: Jurisprudence, vol. 12(2), pp. 183-186.

State Statistics Service of Ukraine (2020). Commodity structure of Ukraine's foreign trade. Available at: http://www.ukrstat.gov.ua/ (accessed 10 November 2020).

Tronenko, N. (2014). Rol yevropeiskykh farmatsevtychnykh TNK u formuvanni spilnoho rynku YeS [The role of European pharmaceutical TNCs in the formation of the EU common market]. Ukrainian securities market, vol. 7, pp. 55-62.

Ustymenko, M. V. (2011). Formuvannia mizhnarodnykh kanaliv rospodilu na farmatsevtychnomu rynku Tsentralnoi i Skhidnoi Yevropy [Formation of international distribution channels in the pharmaceutical market of Central and Eastern Europe]. Marketing in Ukraine, vol. 2, pp. 22-25. 